\title{
Knowing when it's time to go
}

\author{
Vincent Hanlon, MD
}

W elcome to Fort McMurray. We have the energy!" I pass this large, brightly lit sign on the outskirts of the city on my way to the Northern Lights Regional Hospital to work a weekend night shift in the emergency department.

Years ago I lived and worked in Fort McMurray, Alberta, the oilsands capital of the world. Now I'm back on a 6day "road trip" — to visit friends, get a taste of real winter, do a reading from my new book, and work a few shifts.

Several hours and 50 patients later, I recall that welcome sign. We've been going almost nonstop since I arrived at 7pm. It's now 4 in the morning. The ER team is starting to fade. I urgently need to pee and have a snack. It's been catch-up all night, and we're still 2 hours behind. Victims of flu season continue to queue at the admitting desk.

The police arrive with a "headbanger" from the jail — an intoxicated fellow from a bar fight who disliked the spartan decor of his cell and started banging his head against the cement wall. He's brought in handcuffed, with a football helmet taped onto his head. Behind a curtain, a croupy 3-year-old barks spasmodically. Over in the resuscitation area, we're applying the brakes to the irreg-

Dr. Hanlon is a locum emergency physician who lives in Lethbridge, Alberta, and works in various emergency departments around the world, including Alberta, Ontario, and Saudi Arabia.

ularly speeding heart of a middle-aged woman. Feverish heads poke out curiously from behind drawn curtains, taking in the scene, wondering when the doctor is going to get to them.

We've reached the nadir of this night shift — our Mariana trench of one of the longest, coldest nights of

\section{The feeling of exhaustion is at once replaced by a familiar but short-lived euphoria.}

the year. Concentration falters. Mental processes slow. I stifle a yawn each time I introduce myself. My pen stops halfway through a chart note. I struggle to remember the name of an intravenous medication; my brain slips off into a night daydream. I'd like to take refuge in the comfort of a snow drift.

A nurse interrupts my reverie.

"Doctor, Dr. X is on the phone. He wants to speak to you about a patient who was admitted earlier...." X sounds sleepy, his voice a long way off. I shake off my fatigue. He's at home in bed, and his patient's having trouble breathing. Could I please investigate? No problem.

As I hang up the receiver, we hear the PA system click open ominously above our heads. "Code blue. Medicine." Time to go. Grab the crash cart with the defibrillator. We have the energy.

But, for how long? I ask myself, when the shift finally winds down a couple of hours later. The feeling of exhaustion is at once replaced by a familiar but short-lived euphoria. We're still an hour away from sunrise. For me it's been fifteen years of alternating and irregular emergency medicine shift work. Days, evenings, and especially the biorhythmic challenge of nights. I realize it's time for a change.
I think of two of my heroes who inspired me when I was a first-year med student in the late seventies, just starting down the clinical pathway - Wayne, the First, and J.P. II — the Great Ones. And I think of how they have changed over the last two decades.

Wayne and I lived in the same city in those years. His adolescent feats of on-ice derring-do were the talk of our locker room at the University of Alberta. As for J.P. II, I heard the good news of the white smoke rising above the Vatican while on my way to early morning anatomy class. It was the day we dissected the human heart. Table talk around the cadavers was that a coronary artery thrombosis had taken out J.P.'s predecessor and namesake.

Now it's 2000. Number 99 is gone, his neck and back stiff as the life-size cardboard cutout that greets me in my local tire shop. Despite the big smile, I suspect he's in pain. I've noticed my own back starting to 
protest a little after a particularly hard-hitting 12 hours on medicine's front line.

J.P. II has also lost the lightness in his step. He stumbles under the weight of his big hat and the unwieldy mantel of the record, that I sometimes failed to put the biscuit in the basket when it would have made a difference. A big difference. I'm not proud of that.

But I do count a few modest personal bests. A hat trick of elderly hip frac-

\section{Snap off the rubber gloves. Hang up the stethoscope. No backward glances.}

office. Even with my presbyopia I can see what's coming. I watched my father slow, shake, stiffen and eventually stop, as his Parkinson's advanced. First my father, and now my Holy Father.

Should I be worried?

My collection of career records is nowhere near as impressive as those of my heroes. Let me also state, for tures assessed and referred to orthopedics in just over an hour, one icy Saturday morning a few years ago. A unique collection of foreign bodies retrieved from diverse human orifices. And, as I used to say to patients back in the days when there was still time for a little conversation, over the years I've probably put as many stitches into faces as Wayne scored goals. Some prettier than others. I even made a few great saves, admittedly fewer than I imagined I would as an idealistic new grad.

I want to go out while I'm still on top. And if not on top, at least while I can still see the summit. That's not an option for my man in the Vatican, but Wayne knew when it was time to put down the stick, hang up the skates. And he did it with panache.

That's the way I want to go out. Snap off the rubber gloves. Hang up the stethoscope. No backward glances. I imagine it's the way most of us want to go out when we're playing in the game of our lives.

Correspondence to: Dr. Vincent Hanlon, 27 Sunset Rd., Lethbridge AB T1J 4R9; 403 381-1845, fax 403 381-1841, vmhanlon@hotmail.com

\section{Announcing the 2001 winners of the CAEP awards}

$\mathrm{I}$ n 2000, CAEP's Residents' Section worked with the CAEP Board of Directors to develop 2 new national EM awards. "CAEP EM Teacher of the Year" was created to recognize outstanding EM educators in Canada. "CAEP EM Resident Leadership Award" was designed to identify emerging leaders in Canadian EM - a resident who made an exceptional contribution during his or her EM training.

This year, the first year of the Awards, all Emergency Medicine, Pediatrics, and Family Medicine programs were invited to apply. A national Awards Committee met to select the winners. We are pleased to announce those chosen for 2001.

\section{CAEP EM RESIDENT LEADERSHIP AWARD 2001: Dr. Sunil Sookram, Edmonton}

Dr. Sookram has been a standout resident in his FRCP program at the University of Alberta. He has been involved in many endeavours, including CJEM, the STARS program in Alberta, and developing a Trauma Fellowship. He was nominated by his fellow residents as a skilled teacher, a strong resident advocate, and a genuine leader.

\section{CAEP EM TEACHER of the YEAR 2001: Dr. John Ross, Halifax}

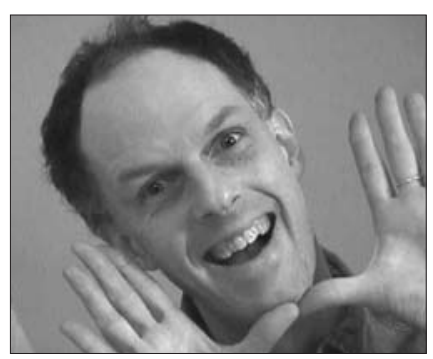

Dr. John Ross

Dr. Ross was nominated by his residents as an unusually dedicated and enthusiastic teacher. $\mathrm{He}$ is known for his ability to skillfully teach learners of all levels and make it enjoyable. He has worked hard to develop EM education in Halifax, including the Teaching Shift project, an airway workshop, and numerous presentations. Dr. Ross was highlighted as an EM role model to be emulated.
Jason R. Frank, MD
Chair
CAEP Residents' Section
Editor
Resident Issues section, CJEM
jfrank@attcanada.ca 